\title{
H3C11 wt Allele
}

National Cancer Institute

\section{Source}

National Cancer Institute. H3C11 wt Allele. NCI Thesaurus. Code C154544.

Human $\mathrm{H} 3 \mathrm{C} 11$ wild-type allele is located in the vicinity of $6 \mathrm{p} 22.1$ and is approximately $1 \mathrm{~kb}$ in length. This allele, which encodes histone H3.1 protein, plays a role in nucleosome formation. 